\title{
SHORT-TERM VOLUNTEERING AND INTERNATIONAL DEVELOPMENT: AN EVALUATION FRAMEWORK FOR VOLUNTEER TOURISM
}

\author{
Fenner School of Environment \& Society, Australian National University, Canberra, Australia \\ Fent School of Environment \& Society, Austalian Nation Unive

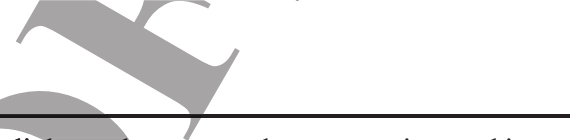 \\ The purpose of this article is to promote debate about the linkages between volunteer tourism and inter- \\ national development, and to argue that volunteer tourism should be assessed as a development activity. \\ Most volunteer tourism activities involve participants from developed countries traveling to volunteer \\ in developing nations, with volunteers largely motivated by the desire to make a positive contribution to \\ their hosts. Volunteer tourism has strong linkages to sustainable tourism, which originated in response \\ to criticisms of mass tourism, including concerns over the negative impacts on hosting communities. In \\ this article I propose a framework to evaluate the potential contributions of volunteer tourism projects \\ to developmental goals. The proposed framework includes four criteria: that volunteers provide skills \\ unavailable locally; that projects form part of a larger development program; that projects prioritize \\ benefit to the host community; and that projects are community driven.
}

Key words: Volunteer tourism; Development; Evaluation; Local ownership; Community driven; Skills transfer

\section{Introduction}

Can volunteer tourism lead to lasting and positive change for communities and organizations in developing countries that host volunteer tourists from developed countries? It is important to answer this question in an environment with many providers advertising holiday opportunities that give participants the chance to "make a difference" (see Ingram, 2008), and with the majority of volunteer tourists seeking a meaningful way of making a positive contribution (see Lough,
McBride, Sherraden, \& O'Hara, 2011). In this article I draw together four key assessment criteria from the literature to develop a formal evaluation framework that can be used by scholars to assess volunteer tourism for its contributions to development, and by volunteer tourism providers to shape and inform their work and practices. The framework provides a lens through which to view volunteer tourism, allowing different volunteer tourism sectors and/or operators to be easily compared and rated for their potential to contribute to development. 


\section{The Origins and Rise of Volunteer Tourism}

The terms "alternative tourism" and "sustainable tourism" are used more or less interchangeably in the literature, to describe "an ideologically divergent form of tourism that is considered preferable to mass tourism and is more sustainable" (McIntosh \& Zahra, 2007, p. 541). It originated in response to criticisms that mass tourism was damaging to the environments, the peoples, and their cultures in the places where the tourist experiences were taking place (Vodopivec \& Jaffe, 2011). Krippendorf (1982) wrote that "tourists demonstrate behaviours and attitudes which can evoke mistrust, resignation and aggressive dissatisfaction in the [local] population" (p. 142). Other criticisms of mass tourism have centered on the difficulties of encouraging cross-cultural understanding in places that have been set up for the purpose of tourist visits (MacCannell, 2001).

Volunteer tourism fits within the broader scope of sustainable tourism (McIntosh \& Zahra, 2007), which is built on the idea of "continued development that does not unduly harm a destination's natural and sociocultural environment" (Weaver, 2006, p. 18). Volunteer tourism is frequently marketed as fitting the ideals of sustainable tourism, providing tourists with the opportunity for a meaningful experience during which they can make a difference, while having a minimal impact on the local environment (Ingram, 2008). It was founded on the principles of development, and benefit for the host community: "Volunteer tourism has its roots in 'volunteerism,' which implies that individuals offer their services to change some aspect of society for the better" (Callanan \& Thomas, 2005, p. 184).

Although there is a broad spectrum of motivations for participating in a volunteer tourism project, the ideas of giving something back and making a contribution to community development are the dominant motivators (see Andereck, McGehee, Lee, \& Clemmons, 2012; Coghlan \& Fennel, 2009). Other volunteers are interested primarily in their own development (see Callanan \& Thomas, 2005; Raymond \& Hall 2008; Simpson, 2004). Regardless of motivations, self-fulfillment and significant changes in outlook on life have been reported by volunteers following volunteer tourism experiences (Lo \& Lee, 2011; Zahra \& McIntosh, 2007).

\section{Volunteer Tourism and Development}

The majority of volunteer tourism involves tourists crossing national boundaries from developed countries to poorer nations, to take part in a volunteer project (TRAM, 2008, cited in Taplin, Dredge, \& Scherrer, 2014). Volunteer tourism covers a broad spectrum of activities and time frames for projects. Some examples of volunteer tourism activities include teaching English to school students, working with school English teachers on their grammar and pronunciation, digging gutters on an ecotourism site, or helping build a dormitory at an orphanage. There is substantial literature on the subject concluding that volunteer tourism is, broadly speaking, a development activity (see Keese, 2011; Vodopivec \& Jaffe, 2011; Wearing \& McGehee, 2013). Regardless of the stated purpose of volunteer tourism projects that occur in developing countries, there will be impacts on local communities, whether that is in the form of skill transfer from the visitors (Lough et al., 2011), displacement of local people from their beaches or fields (Goodwin, 2008), or some other impact.

Butcher and Smith (2010) and Palacios (2010) argue that to view volunteer tourism as a development activity is misplaced. They argue that framing volunteer tourism in terms of development leads to unfulfilled expectations on the part of the volunteers and frustrations on the part of their hosts. According to Palacios (2010), volunteer tourism must be framed as an experience to foster and promote intercultural understanding.

\section{Criticisms of Volunteer Tourism}

Contrary to the intercultural view outlined above, others find that contact does not automatically equate with cross-cultural understanding. Existing stereotypes of Western dominance can be reinforced, because the volunteer tourist is coming to "help locals" who are presumed to have less knowledge and worldliness (see Guttentag, 2009; Raymond \& Hall, 2008). Inexperienced volunteers are told they can "make a difference" when their lack of skills and knowledge makes them more likely to be a burden than an asset to the hosting community (Simpson, 2004). The short-term nature of most volunteer tourism projects results in an oversimplification of 
international development, and this has the potential to undermine longer term development initiatives (Simpson, 2004). Crabtree (2008) notes that volunteer tourism projects can reinforce the idea that development is not something local communities can achieve themselves, but is something that requires outsiders to come and "do" on their behalf. Guttentag (2009) discusses other negative impacts that host communities may face, including possible neglect of locals' desires, disruptions to work progress, and unsatisfactory work being done by volunteers, as well as local economies being disrupted by free labor.

\section{Existing Evaluations of Volunteer Tourism}

Within the existing body of literature on volunteer tourism projects and the experiences of volunteers and host communities are a number of implicit criteria for evaluating the contributions to development of individual projects and volunteer tourism more generally. There are articles that analyze individual volunteer tourism projects (e.g., Palacios, 2010), articles that evaluate volunteer tourism projects that have the objective of transforming attitudes in the developed world (e.g., Ollif, 2001), and articles that assess some of the impacts on single locations receiving large numbers of volunteer tourists (e.g., Lough et al., 2011). These articles refer to development in general; however, each article has its own methodology and system for evaluation. The majority evaluate the experiences of the volunteers, while a few consider the impacts on the host community (e.g., Guttentag, 2009). Table 1 presents a critique of key articles that contain evaluations of volunteer tourism.

\section{Frameworks for Analysis of Volunteer Tourism}

Although there is little published explicitly on a systematic evaluation of volunteer tourism, there is one article proposing an analytical framework for volunteer tourism providers and researchers to use as a basis for assessing, monitoring, and evaluating volunteer tourism projects. Taplin et al. (2014) discuss how challenging it is to monitor and evaluate volunteer tourism programs because of difficulties in defining exactly what constitutes volunteer tourism. They argue that the stated objectives and context of the particular project or program needs to be considered before monitoring and evaluation can take place. Taplin et al. (2014) place the onus for conducting monitoring and evaluation of volunteer tourism projects on volunteer tourism organizations themselves, and discuss methods of conducting monitoring and evaluation that mitigate the influence of existing unequal power relationships among the different stakeholders. Requiring volunteer tourism organizations to evaluate their own programs makes comparison of different operators and sectors difficult, and creates the potential for a conflict of interest.

Jafari (2001) used a typology of four platforms to describe research responses to mass tourism (advocacy, cautionary, adaptancy, and scientific). Jafari's (2001) description of advocacy referred to research promoting tourism as bringing benefits to host communities with few if any negative impacts. Following this, a cautionary platform emerged with research that focused on the negative impacts that were being observed; then followed adaptancy research examining ways to maximize positive impacts on host communities and at the same time minimize negative impacts. Jafari's (2001) final platform was the scientific platform, which sought to bring a more logical and systematic approach to research on mass tourism. Wearing and McGehee (2013) comment that close examination of research into volunteer tourism reveals these same platforms. They further note that there is a growing trend in the literature to focus on the adaptancy platform of seeking ways to mitigate negative impacts and promote positive impacts.

Sustainable tourism and volunteer tourism were founded to promote development and address global inequities. It is therefore reasonable to argue that volunteer tourism projects be assessed against their potential to contribute to development and the wellbeing of the communities and community members in volunteer tourism project locations. Furthermore, I argue that regardless of the stated purpose of any particular volunteer tourism projects, their design and structure should be critically examined to determine their potential to contribute to development. To date the literature on volunteer tourism and its relationship to development has been overwhelmingly critical. From a development perspective, the impacts on the host community are of primary importance. 


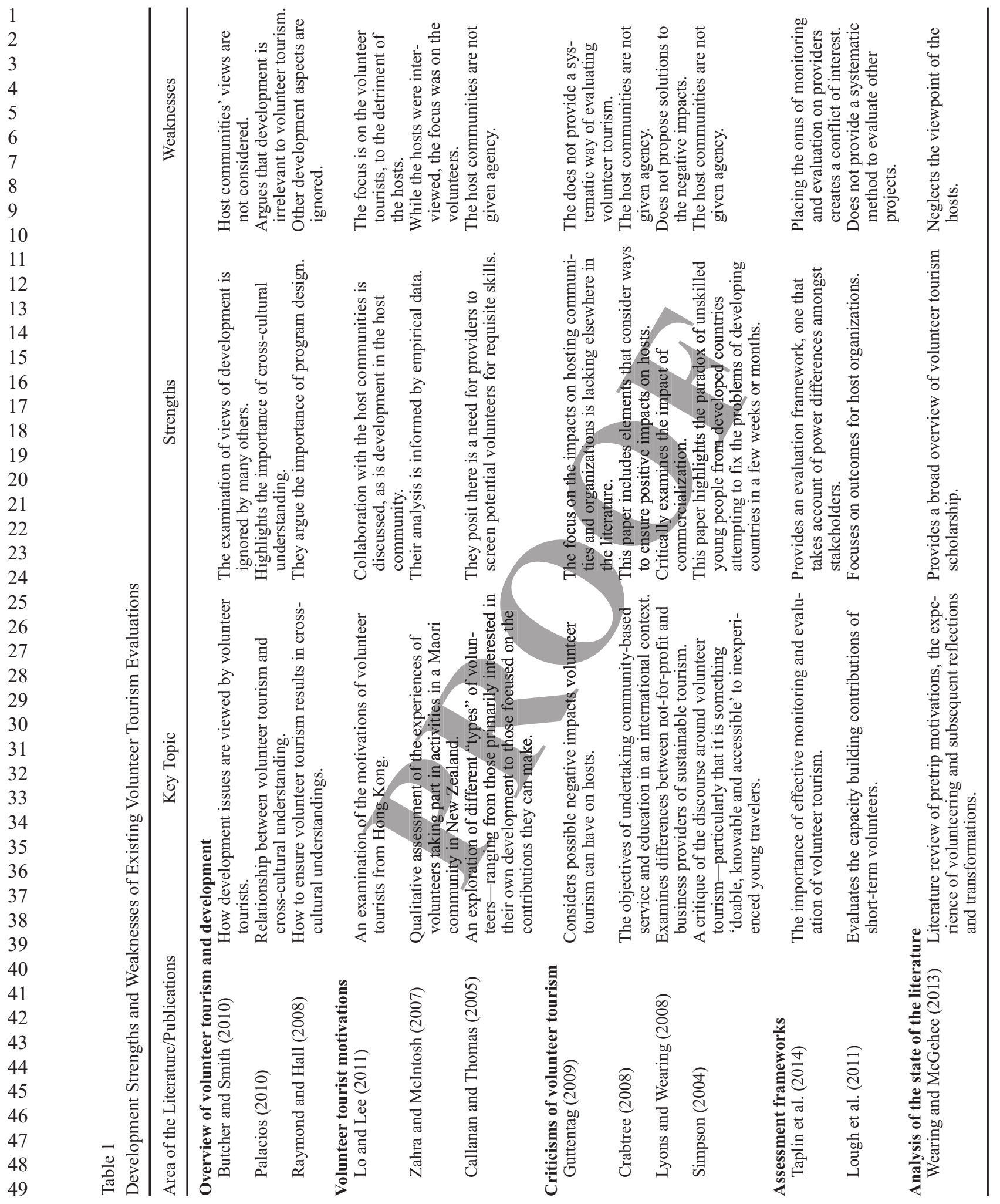


Need for an Independent Evaluation Framework

To explore whether or not the design of volunteer tourism projects and programs supports development work, it is useful to define what is meant by the word development. Academics and practitioners alike consider development to correlate with the advancement of a people, community, or nation. Advancement refers to a long-term change, not a short-term spike in well-being (see Bolton, 2008; Dembitzer, 2009; Hanlon \& Smart, 2008). There is a large body of literature that discusses "sustainable development," as defined in the Brundtland report: "Humanity has the ability to make development sustainable - to ensure that it meets the needs of the present without compromising the ability of future generations to meet their own needs" (Brundtland Commission, 1987, p. 8).

As outlined, Jafari's (2001) adaptancy platform refers to efforts to minimize the negative impacts of tourism on hosts, and maximize the positive impacts. Management of the impacts on hosts is likewise important for volunteer tourism. For volunteer tourism to contribute to development, each project (or group of projects) must be assisting in the long term advancement of the people and community in that location. For that development to be sustainable the possibility of negative intergenerational consequences should be considered and efforts made to mitigate them.

Taplin et al. (2014) argue that provision of prescriptive methods for carrying out monitoring and evaluation is inappropriate as each volunteer tourism project must be evaluated against its stated objectives. They have discussed monitoring and evaluation in detail, including how volunteer tourism organizations can use sophisticated monitoring and evaluation tools to ensure that the existing power disparities do not influence the gathering of data. There are two weaknesses in their approach in terms of the development contributions of volunteer tourism projects. The first is that although the inputs for monitoring and evaluation come from stakeholders in volunteer tourism ventures, one of those stakeholders is responsible for conducting the evaluation. Particularly with the increasing commercialization of volunteer tourism (see Lyons \& Wearing, 2008; Taplin et al., 2014), placing the onus on volunteer tourism providers to conduct the monitoring and evaluation creates a conflict of interest. The second weakness is the focus on the outcomes of volunteer tourism projects, as experienced by the different stakeholders. This is problematic because developmental change, being a long-term goal, is not likely to be perceptible immediately following a short project. Evaluating the structure and design provides a broader scope through which to examine volunteer tourism.

As I have argued, volunteer tourism project and program design in developing countries should be examined for its ability to contribute to development. Academics and practitioners alike concern themselves with the time it takes to implement development activities. Hanlon and Smart (2008) argue that, "One of the fundamental 'governance' problems is that aid workers are in Mozambique for only two years and the Mozambican government is elected for five years; they want change within their tenure, yet . . . developmental change often takes longer than that" (p. 72).

If 2 years spent by an aid worker or 5 years by a national government is not enough time to enact developmental change, then the design of short-term volunteer tourism projects must be very carefully assessed to ensure they can contribute to development efforts, rather than undermining them.

To understand the contributions of volunteer tourism to development, the input of the different stakeholders in volunteer tourism projects is important. The feedback provided by these stakeholders should be analyzed by development experts to determine not only how different actors feel about volunteer tourism projects, but also what the impacts of volunteer tourism projects will likely be over 5, 10 , or 20 years. In addition, assessment of project and program design is important to ensure that the structure of volunteer tourism projects facilitates positive contributions to development.

There is a growing push for evaluations of projects, including of the experiences of host communities, host organizations, and volunteers. However, to date it has been largely left to volunteer tourism organizations themselves to evaluate volunteer tourism projects, and there has been little study about whether evaluations are taking place at all (Taplin et al., 2014). Another issue brought up in the literature is that host communities may be cautious 
when it comes to assessing projects, because of a perception that explicit criticism may cause offence or lead to a loss of funding ( $\operatorname{Sin}, 2010)$.

In this article I draw on existing ideas in the literature to develop a framework that can be used to assess individual project design, the design of projects in a particular sector, or the design of projects being run by a particular organization. This article will add value to the volunteer tourism literature, as through the application of an evaluation framework to volunteer tourism project design, a strong empirical evidence base with a large number of comparable cases can be developed. This will support the examination of the ideas involved in volunteer tourism in a way that is grounded in reality, thereby promoting more nuanced and sophisticated intellectual understandings of volunteer tourism and its relationship to development.

\section{The Framework}

The evaluation framework that I propose can be used to assess volunteer tourism projects and program design and can be extrapolated to assess volunteer tourism more generally at a provider or sector level. The proposed framework brings together from the literature those key elements of volunteer tourism that have an impact on development in poor countries, and is informed by the critiques of others and my own experience both as a volunteer tourist and as a development practitioner. This framework is important and timely as the literature that critically evaluates the impacts that volunteer tourism has on host communities is growing. Use of this lens will allow critical evaluation's of volunteer tourism across sectors and providers to be easily compared. Table 2 shows the criteria that make up this framework.

Each of these criteria will be explored in detail below, with discussions of why each is important, and why each makes it more likely that projects will lead to benefits for local people. The criteria relate to the process and structure of volunteer tourism projects and programs, rather than focusing on outcomes and the views of stakeholders. Following the exploration of criteria, I apply the framework to two case studies.

There are many different groups that organize volunteer tourism including not for profits, religious organizations, and businesses. The criteria included in the framework are applicable to any sector/of volunteer tourism; however, there is growing concern in the literature about the increasingly commercial nature of volunteer tourism (see Lyons \& Wearing, 2008; Taplin et al., 2014). For this reason I use commercial volunteer tourism to exemplify parts of these criteria.

\section{Criterion 1: Providing Skills That} Are Unavailable Locally

Some of the literature on volunteer tourism reports that short-term volunteers can make direct contributions to the organizational capacity of their host organizations. Lough et al. (2011) highlight host organizations' reports of new ideas being introduced, increased intercultural competence of staff, and transfer of knowledge and technical/professional skills from volunteers to staff. The host organizations interviewed by Lough et al. (2011) were pleased to have international volunteer tourists because of what their staff could learn from the volunteers.

Table 2

Assessment Criteria

\begin{tabular}{ll}
\hline Assessment Criteria & \multicolumn{1}{c}{ Sources } \\
\hline $\begin{array}{l}\text { 1. Volunteers are providing skills not available } \\
\text { locally. }\end{array}$ & Guttentag (2009), Lough et al. (2011) \\
$\begin{array}{l}\text { 2. Projects form part of a broader development } \\
\text { program. }\end{array}$ & Ingram (2008), Lough et al. (2011) \\
$\begin{array}{l}\text { 3. Benefit to the host community is prioritized. } \\
\text { Guttentag (2009), Lyons and Wearing (2008), Simpson (2004), } \\
\text { Taplin et al. (2014) }\end{array}$ \\
$\begin{array}{ll}\text { 4. Projects are initiated and driven by the } \\
\text { community. }\end{array}$ & Hailey (1999), Porritt (2013) \\
\hline
\end{tabular}


Others describe volunteer tourists who might typically "participate in eco-camps where teams plant trees, lay out pathways through nature reserves, or erect fences and protective barriers" (Sherraden, Stringham, Sow, \& McBride, 2006, p. 167). Unskilled volunteers doing this type of work are providing free labor which can result in "a decrease in [local] employment opportunities and a promotion of dependency, caused by the presence of volunteer labour" (Guttentag, 2009, p. 537). This is not only true of unskilled labor; when volunteer tourists are providing skills that could be sourced from the local labor market, they are causing the same decrease in local employment opportunities.

For the volunteer program design to contribute to developmental change, not only should the volunteer bring new skills, there should also be the opportunity for local people and volunteers to interact and learn from each other. Where volunteers come into a community as individuals and work alongside a person or people from that community there is a reasonable possibility of a two-way sharing of ideas, knowledge, skills, and language. Where the volunteers come as a group they are far less likely to share their ideas and knowledge with local people. Overcoming language and cultural barriers is challenging and takes energy and time. Consequently, it is often easier for volunteer tourists to just mix with other members of their group rather than with the local population.

\section{Criterion 2: Broader Development Program}

There is an old Chinese proverb that says, "Give a man a fish and you feed him for a day; teach a man to fish and you feed him for a lifetime." This proverb describes the importance of what is inside people, as opposed to the material things that surround them. Giving someone food or money does not change who they are. Once they have eaten the food or spent the money they will be in the same situation as they were before they received it. On the other hand, once someone has acquired a new skill or understanding, it cannot be taken away from them. This philosophy lies at the root of development work, which is designed to facilitate long-term change (Bolton, 2008). Development work is complicated though, and in order to truly assist in developmental change it is necessary to work with local people, understand their culture, and spend the time finding underlying causes of underdevelopment before implementing solutions (Ingram, 2008).

Volunteer tourism projects are short term in nature, with volunteers often participating for a month or less (Guttentag, 2009). This makes it difficult for an individual volunteer tourist or single group of volunteer tourists to be effective as there is insufficient time for the individual or group to develop an understanding of the host community and the root cause of problems to be addressed. There should therefore be, for example, a development worker or organization to fulfill those tasks of understanding the local community and working with them to plan appropriate interventions. Interventions themselves are likely to also require long-term delivery, and this is where it is useful to have a structured program where waves of volunteer tourists come and build on the work of the preceding cohorts. The literature does include examples of volunteer sending organizations that repeatedly send volunteers to the same organizations in the same geographic locations (e.g., Lough et al., 2011). Although this allows for one volunteer to continue the work of an earlier volunteer, the literature does not include examples of formal and structured efforts to ensure volunteers are effectively and efficiently building on the work of their predecessors.

In an effort to address this issue, and for a volunteer tourism project to be considered as part of a broader development program, a structure that ensures the continuity of skills transfer is necessary. By linking volunteer tourism programs into larger projects, volunteers can make small contributions within a development program that has long term objectives. As stated, the task of ensuring continuity of skills transfer does not need to be done by the volunteer tourists themselves, but could, for example, be done by a development worker who works with the host community in a long-term role and, in conjunction with them, directs the volunteer tourist activities.

\section{Criterion 3: Project Design Prioritizes the Benefit to the Host Community}

Much of the literature on volunteer tourism reflects on whether volunteers are motivated by altruism or whether their ultimate goal is to help 
themselves through the experience (see Butcher \& Smith, 2010; Lough et al., 2011; Simpson, 2004). There is a general trend in the literature to allow that volunteer tourism can be beneficial for both the volunteer and the host community (see Guttentag, 2009; Taplin et al., 2014).

Prioritizing benefit to the host community does not have to be detrimental to the volunteers' experience. It is clear that one of the predominant reasons for volunteering is to "make a contribution" and to "give something back"; in other words, the paying volunteer wants the host community to receive the primary benefit. There is a conflict, however, because volunteer tourism is becoming increasingly commercialized and profit driven (Lyons \& Wearing, 2008). Volunteers who participate in volunteer tourism projects often pay quite large fees to do so (Simpson, 2004). This can lead to commercial providers prioritizing the volunteers over the host community (Guttentag, 2009), and as the host community does not pay they are unlikely to receive the same attention as the volunteers. Unless the experience of hosting volunteers is terrible, however, the community is unlikely to break the relationship with the company sending the volunteers because in the short term, volunteer tourists bring money into the community.

Because it cannot be presumed that the stakeholders in volunteer tourism projects are development experts it is important that the design of projects prioritizes benefit to host communities. This will help ensure that volunteer tourism projects make positive developmental contributions to host communities.

\section{Criterion 4: Community Initiated and Driven}

One of the buzz phrases in development work is "local ownership." This phrase refers to the importance of the people in a local community placing value on projects in their community, and having a sense of control and ownership of the project. Burnell (1998) argues that community support is an essential criterion for development to have sustainable outcomes, while Hailey (1999) emphasizes that grass-roots support strongly increases the chances of sustainable outcomes. If the members of the local community did not have a say in setting up the project, they are far less likely to value it, and consequently are far less likely to try and maintain it after the departure of the outsiders. Although local people might display an enthusiastic response to the presence of foreigners while they are around, it is what happens after the volunteer tourists depart that is important.

With local ownership comes participation, which is an essential component of development work (Hailey, 1999). Sustainable development encompasses a huge variety of activities, from community development through to environmental management. For any of these activities to deliver long-term benefits they must be "rooted in and permanently nurtured by their host communities" (Porritt, 2013, p. xi).

\section{Applying the Framework}

In this section I apply the framework to two case studies to illustrate its utility. One of these is from the popular media and the other from the academic literature. These show how the framework can be used, including the sorts of questions those conducting evaluations could ask for each of the criteria in different volunteer tourism project settings, as shown in Table 3 and Table 4. I have also included an indicative assessment of each case.

\section{Case Study One: House Painting in Ecuador}

An article published in the Guardian newspaper in 2003 includes an example in Ecuador of volunteer tourism: "A team of students had been sent to 'help the local community.' The villagers returned home from work to discover their houses had been painted by the volunteers without prior consultation" (Brown, 2003).

The overall assessment of the volunteer tourism project assessed against the framework is that it is unlikely that criterion 1,2 , or 3 were favorably met, and it is clear that it failed to meet criterion 4 . This is an example of volunteer tourism gone wrong.

\section{Case Study Two: Organizational Capacity Building in Peru}

Lough et al. (2011) studied a US-based volunteer sending agency that has facilitated the placement of "non-expert" volunteers with organizations in the 
Table 3

Assessing the "House Painting in Ecuador" Project

\begin{tabular}{|c|c|c|}
\hline Criteria & $\begin{array}{l}\text { Indicative Questions to ask in } \\
\text { Order to Assess the Criteria }\end{array}$ & Assessment \\
\hline $\begin{array}{l}\text { Are the volunteers providing } \\
\text { skills that are unavailable } \\
\text { on the local labor market? }\end{array}$ & $\begin{array}{l}\text { Would the local population have had the } \\
\text { skills to paint their own houses? }\end{array}$ & $\begin{array}{l}\text { It seems unlikely that the volunteers were doing } \\
\text { work that could not have been done by local } \\
\text { people. }\end{array}$ \\
\hline $\begin{array}{l}\text { Did this project form part } \\
\text { of a broader development } \\
\text { program? }\end{array}$ & $\begin{array}{l}\text { Did the house painting project link to a } \\
\text { broader project around (for example) } \\
\text { mosquito control/eradication? }\end{array}$ & $\begin{array}{l}\text { Since the local population were not consulted } \\
\text { regarding the painting of their houses, it appears } \\
\text { unlikely that this project was part of a broader } \\
\text { systematic program. }\end{array}$ \\
\hline $\begin{array}{l}\text { Was benefit to the host } \\
\text { community prioritized? }\end{array}$ & $\begin{array}{l}\text { Did the villagers want their houses } \\
\text { painted? } \\
\text { Did this project improve (for example) } \\
\text { the structural integrity of the houses? }\end{array}$ & $\begin{array}{l}\text { Since the villagers were not consulted about the } \\
\text { house painting it appears unlikely that there } \\
\text { was an engineering assessment of the houses } \\
\text { involved. }\end{array}$ \\
\hline $\begin{array}{l}\text { Was the project community } \\
\text { initiated and driven? }\end{array}$ & Whose idea was it to paint the houses? & $\begin{array}{l}\text { It is clear that this project was not initiated by the } \\
\text { host community and nor was it driven by them. }\end{array}$ \\
\hline
\end{tabular}

town of Villa El Salvador in Peru. Over the period 1999-2010 around 1,500 people volunteered their services in Villa El Salvador through the one USbased organization, averaging 4 weeks per person. Prospective volunteers would complete an application. This would be reviewed by the sending organization, which tried to match host organization needs with prospective volunteers' interests and skills. Volunteers did not require any specific skills in terms of language, education, or work experience. Lough et al. (2011) assessed five host organizations against five similar organizations that do not host volunteers, based on interviews with three staff members from each organization.

The overall assessment of this program of sending volunteers is that it appears to provide reasonable benefit to the hosting organizations. There is a possibility that the hosts may become dependent on the philanthropy they receive from current and former volunteers. The program could be improved by focusing more on the ongoing needs of the host organizations and providing a structure to ensure volunteers are able to build on the work of previous cohorts of volunteers. Despite this, it is apparent that volunteers provided useful skills, and that their presence was valued by their hosts.

These two case studies show a methodology of use for the framework. The first case does not include sufficient detail for a thorough analysis to be made, and the conclusions are largely drawn through deduction. The second case provides much more substantial information from which to draw direct conclusions. These examples highlight the possibilities for assessing volunteer tourism as described in the literature, as well as direct assessment of current and ongoing projects.

\section{Conclusion}

Volunteer tourism originated as part of a move to mitigate against the negative impacts of mass tourism, and to ensure positive outcomes for communities hosting tourists. The volunteers who participate in volunteer tourism activities are largely motivated by a desire to give something back or to make a difference, and the majority of volunteer tourism involves people from the developed world traveling to the developing world. Whatever the stated objectives of a volunteer tourism project, it will have both positive and negative impacts on the host community. For all the above reasons, volunteer tourism must be critically assessed as a development activity.

The existing literature on evaluation of volunteer tourism projects largely focuses on lay people's perceived outcomes of the projects, and has limited utility in assessing the potential for volunteer tourism to contribute to development. The framework outlined in this article can be used by researchers to assess the design of volunteer tourism projects and programs, and their ability to contribute to developmental change. It consists of four criteria: volunteers bringing useful skills; projects forming part of a larger development program; project design 


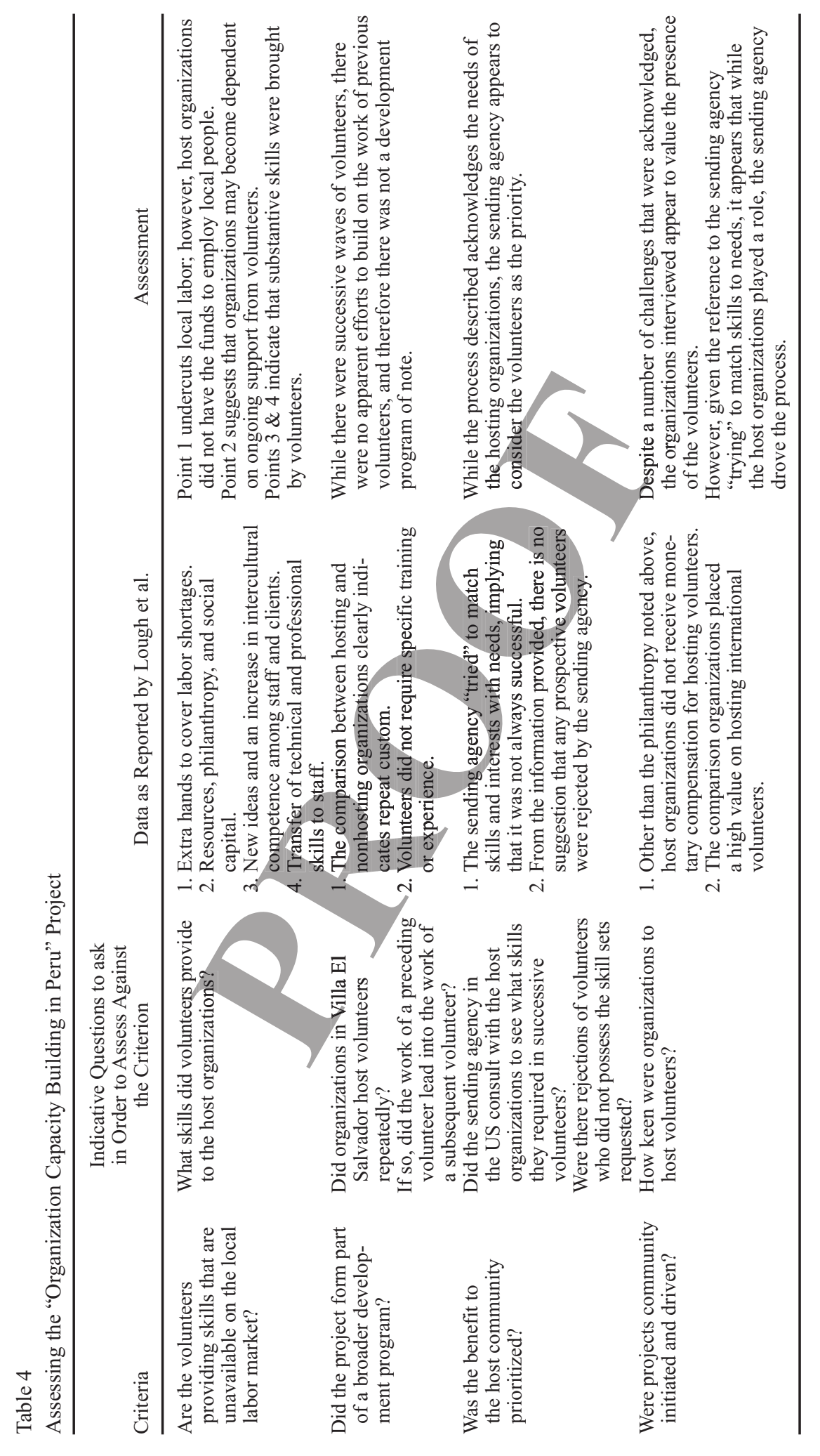


prioritizing benefits to the host community; and projects being community driven. The structural potential for volunteer tourism projects and programs to contribute to sustainable development can be assessed using these criteria. It will also enable researchers to assess, compare, and contrast the project and program design of different volunteer tourism organizations.

The proposed framework has been applied to two case studies to illustrate its utility in capturing data from projects, sectors, and volunteer tourism providers. Gathering information on volunteer tourism projects and the volunteer tourism sector through the use of a framework such as the one I have outlined will allow the capture of data sets that are comparable with each other. This will facilitate the creation of a large empirical body of data that will help build a more nuanced understanding of volunteer tourism and how it fits in with and relates to development.

\section{Acknowledgments}

I would like to thank my wife, Dr. Beth Gilfillan, for her patience in reading and providing constructive criticism on each draft of this article. I would also like to thank Mr. Andrew Nuss, Ms. Annie Rushton, Mrs. Julie Gilfillan, Mr. Malcolm Gilfillan, Ms. Lisa Bush, Mr. Chris Hollonds, and Mr. Kim Gilfillan for their thoughts and input. Finally, I would like to thank the two anonymous reviewers for their constructive and helpful feedback.

\section{References}

Andereck, K., McGehee, N. G., Lee, S., \& Clemmons, D. (2012). Experience expectations of prospective volunteer tourists. Journal of Travel Research, 51(2), 130-141.

Bolton, G. (2008). Aid and other dirty business: An insider uncovers how globalisation and good intentions have failed the world's poor. Reading, UK: Random House.

Brown, P. (2003, September 6). Mind the gap: Why student year out may do more harm than good. The Guardian. Retrieved October 15, 2014, from http://www.theguard ian.com/uk/2003/sep/06/highereducation.gapyears

Brundtland Commission. (1987). World commission on environment and development, our common future. Oxford, UK: Oxford University Press.

Burnell, P. (1998). Britain's new government, new white paper, new aid? Eliminating world poverty: A challenge for the 21st century. Third World Quarterly, 19(4), 787-802.
Butcher, J., \& Smith, P. (2010). "Making a difference": Volunteer tourism and development. Tourism Recreation Research, 35(1), 27-36.

Callanan, M., \& Thomas, S. (2005). Volunteer tourism: Deconstructing volunteer activities within a dynamic environment. In M. Novelli (Ed.), Niche tourism. Contemporary issues, trends and cases Oxford, UK: Elsevier Butterworth-Heinemann.

Coghlan, A., \& Fennell, D. (2009). Myth or substance: An examination of altruism as the basis of volunteer tourism. Annals of Leisure Research, 12(3-4), 377-402.

Crabtree, R. D. (2008). Theoretical foundations for international service-learning. Michigan Journal of Community Service Learning, 15(1), 18-36.

Dembitzer, B. (2009). The attack on world poverty: Going back to basics. Pontypool, Wales: Ethical Events.

Goodwin, H. (2008). Pro-poor tourism: A response. Third World Quarterly, 29(5), 869-871.

Guttentag, D. A. (2009). The possible negative impacts of volunteer tourism. International Journal of Tourism Research, 11(6), 537-551.

Hailey, J. (1999). Ladybirds, missionaries and NGOs. Voluntary organizations and co-operatives in 50 years of development: A historical perspective on future challenges. Public Administration and Development, 19(5), 467-485.

Hanlon, J., \& Smart, T. (2008). Do bicycles equal development in Mozambique? Woodbridge, UK: Boydell \& Brewer Ltd.

Ingram, J. M. (2008). Volunteer tourism: Does it have a place in development? Honors dissertation, University of Tasmania, Tasmania, Australia.

Jafari, J. (2001). The scientification of tourism. In V. L. Smith \& M. Brent (Eds.), Hosts and guests revisited: Issues of the 21st century (pp. 28-41). Elmsford, NY: Cognizant Communication Corporation.

Keese, J. R. (2011). The geography of volunteer tourism: Place matters. Tourism Geographies, 13(2), 257-279.

Krippendorf, J. (1982). Towards new tourism policies: The importance of environmental and sociocultural factors. Tourism Management, 3(3), 135-148.

Lo, A. S., \& Lee, C. (2011). Motivations and perceived value of volunteer tourists from Hong Kong. Tourism Management, 32(2), 326-334.

Lough, B. J., McBride, A. M., Sherraden, M. S., \& O'Hara, K. (2011). Capacity building contributions of short-term international volunteers. Journal of Community Practice, 19(2), 120-137.

Lyons, K. D., \& Wearing, S. (2008). Volunteer tourism as alternative tourism: Journeys beyond otherness. In K. Lyons \& S. Wearing (Eds.), Journeys of discovery in volunteer tourism: International case study perspectives (pp. 3-11). Cambridge, UK: CABI.

MacCannell, D. (2001). Remarks on the commodification of cultures. In V. L. Smith \& M. Brent (Eds.), Hosts and guests revisited: Tourism issues of the 21st century (pp. 380-390). Elmsford, NY: Cognizant Communication Corporation. 
McIntosh, A. J., \& Zahra, A. (2007). A cultural encounter through volunteer tourism: Towards the ideals of sustainable tourism. Journal of Sustainable Tourism, 15(5), 541-556.

Ollif, C. E. (2001). Can 28 days make a difference? A case study of community aid abroad's community leadership program. Australian Geographical Studies, 39(3), 353-364.

Palacios, C. M. (2010). Volunteer tourism, development and education in a postcolonial world: Conceiving global connections beyond aid. Journal of Sustainable Tourism, 18(7), 861-878.

Porritt, J. (2013). Foreword. In D. Warburton (Ed.), Community and sustainable development: Participation in the future (pp. xi-xiv). London, UK: Routledge.

Raymond, E. M., \& Hall, C. M. (2008). The development of cross-cultural (mis)understanding through volunteer tourism. Journal of Sustainable Tourism, 16(5), 530-543.

Sherraden, M. S., Stringham, J., Sow, S. C., \& McBride, A. M. (2006). The forms and structure of international voluntary service. Voluntas: International Journal of Voluntary and Nonprofit Organizations, 17(2), 156-173.

Simpson, K. (2004). "Doing development": The gap year, volunteer-tourists and a popular practice of development. Journal of International Development, 16(5), 681-692.

Sin, H. L. (2010). Who are we responsible to? Locals' tales of volunteer tourism. Geoforum, 41(6), 983-992.

Taplin, J., Dredge, D., \& Scherrer, P. (2014). Monitoring and evaluating volunteer tourism: A review and analytical framework. Journal of Sustainable Tourism, 22(6), 874-897.

Vodopivec, B., \& Jaffe, R. (2011). Save the world in a week: Volunteer tourism, development and difference. European Journal of Development Research, 23(1), 111-128.

Wearing, S., \& McGehee, N. G. (2013). Volunteer tourism: A review. Tourism Management, 38, 120-130.

Weaver, D. B. (2006). Sustainable tourism: Theory and practice. London, UK: Routledge.

Zahra, A., \& McIntosh, A. J. (2007). Volunteer tourism: Evidence of cathartic tourist experiences. Tourism Recreation Research, 32(1), 115-119. 